\title{
"Impact of Perceived Risk on Consumer Purchase Intention towards Luxury Brands in Case of Pandemic: The Moderating Role of Fear"
}

\author{
RIMSHA KANWAL \\ Research Scholar \& Visiting Lecturer, \\ Institute of Banking and Finance, \\ Bahauddin Zakariya University, Multan, Pakistan. \\ Email: rimshakanwal177@yahoo.com
}

\begin{abstract}
This paper explores the relationship between perceived risk, fear, and consumer purchase intention towards luxury brands in the case of COVID-19. An online survey was conducted on 750 consumers of luxury brands in Pakistan with a purposive sampling technique. The validity of the scale and the connection between the research model were identified by exploratory factor analysis (EFA). The study uncovered how COVID-19 wreaks havoc on luxury brands in Pakistan. It was found that perceived risk has a negative and significant effect on consumer purchase intention towards luxury brands in the case of COVID-19. Moreover, fear negatively moderating the relationship between perceived risk and consumer purchase intention towards luxury brands in the case of COVID-19. As fear playing a dominant role in the reduction of purchase intention in the case of an outbreak, a brand's industry needs to prepare some strategies in advance that control the negative emotions of consumers for shopping. Considering the uniqueness of the study, it is based on two theories include Psychometric Paradigm and Expectancy-Value model that explains how perceived risk changes the consumer purchase intention during an outbreak.
\end{abstract}

Keywords: COVID-19, Perceived Risk, Fear, Consumer Purchase Intention, Luxury Brands.

\section{Introduction}

The novel coronavirus disease is a progressing pandemic, also called a COVID-19 that was first introduced in Wuhan city of China in 2019 December. It was declared a pandemic on 11 march, 2020 because it spread over multiple countries (Huang et al., 2020). It is a horrible downturn in the worldwide market (Chen et al., 2020). It continuously causing disruption globally and hampering companies' strategies, Gucci also canceled its cruise fashion show on 18 may that was expected to host in San Francisco in 2021 (Strahilevitz, 2020). It is spreading rapidly and people are in the great depression of life and death. All businesses have been suffered from this outbreak especially those businesses that are discretionary in nature and luxury businesses are one of the most discretionary businesses. The idea of luxury is like something fashionable and alluring (Kapferer and Bastien, 2009). Luxury brands have been described are those brands in which the ratio of intangible utility to price is high and the ratio of functional utility to price is low means premium quality and higher price (Kapferer \& Valette-Florence, 2018). Today luxury brand consumers are experiencing a perceived risk and insecurity to a great extent because shoppers took a big hit to their financial security. Perceived risk is the subjective judgment of peoples about the probability of negative occurrence e.g., fraud, Injury, disease, illness, infection, natural disaster, and death (Grima et al., 2019). Perceived risk has a negative effect on consumer buying behaviour (Zheng et al., 2012). Luxury executives can't ignore the psychology of luxury consumers (Ruiz-Mafe et al., 2018). The purchase of the luxury brands industry is fully dependent on consumer's emotions either negative or positive and when 
consumers are in crisis it's hard to dream about luxury brands because they are focusing on day-to-day transactions. Fear is the negative emotions or the overestimation of risk that abstains consumers from going into danger through avoidance behaviour and withdraw or escape rapidly from the forthcoming situation.

This existing paper evaluates the factors that influencing consumer purchase intentions towards luxury brands in Pakistan as the brand's industry are affected by COVID-19 (Sethi, 2020; Khan, 2020). Although in many circumstances it has been seen that perceived risk leads to a change in purchase intention, higher the level of the risks the lower purchase intention (Lobb et al.,2007; Hutjens, 2014), however, fear emotion is not including here, on the other side when consumer have negative emotion (fear) about forthcoming then it rapidly swings purchase intention. So, this is debatable and implies that fear might be working as a moderator between perceived risk and purchase intention. This will be determined in this current research. This study may add a valuable contribution to the existing understanding of fear as it focuses on the relation of risk and purchase intention in the case of COVID-19.

The study focuses on luxury brands that are notable nationally and internationally in Pakistan include Armani, Nike, Zara, Puma, Adidas, Levi's, Khaadi, Maria B, Junaid Jamshed, Generations, Deepak Sherwani, Chinyere, Amir Adnan, Ammar Bilal, and many others. In Pakistan, not only elite class purchasing luxury brands, but even common people also purchasing them and the reason is that luxury brands also have created some specific product lines for a common class like Armani has Emporio Armani, Giorgio Armani, Armani Jeans, and Armani exchange (Shaikh et al., 2017). This research is fortunate, because of the expanding call for the paper by researchers, on the different factors that are influencing consumer purchase intention in this outbreak (Xu et al., 2020). The current paper used two influential theories, the psychometric paradigm and expectancy-value model which explain the relation of perceived risk and purchase intention in the case of coronavirus outbreak.

\section{Research Questions}

This paper tried to find the answer to the following questions: what is the influence of perceived risk on consumer purchase intention towards the luxury brand in the case of the COVID-19? What is the relation between perceived risk and fear in the case of the COVID-19? And does fear negatively strengthen the relationship between perceived risk and purchase intention toward luxury brands in the case of the COVID-19? The structure of the paper is consisting of the literature review and hypothesis, research methodology, result, discussion, and finally the conclusion.

\section{Literature Review}

\section{Theories}

\section{Psychometric Paradigm and Expectancy-Value model}

The psychometric paradigm approach is used to explain how people (non-expert) perceived dangerous risks (hazards) (Slovic., 2000). Two dimensions of perceived risk have been principally dominated by the psychometric paradigm approach, include a cognitive risk and emotion risk (Oh et al., 2015). According to the cognitive dimension, people's knowledge, familiarity, and controllability about risk decide how they would perceive it. People consider a hazard to be very serious or risky when they have less knowledge or unfamiliar with it, and cannot control it (Bonnet et al., 2012). The emotion dimension also called the affective dimension of risk that is related to people's feelings regarding danger outcome (Lee et al., 2010). It has been defined by characteristics such as high dread and immediacy (Lee et al., 2010; Oh et al., 2015). High dread is the feeling of scare that is incited when the people feel the outcomes of a dangerous situation would be very serious Fung et al., 2011). During the hazard situation, another important characteristic of the affective dimension that people may include when judging the riskiness of hazard is known as the degree of immediacy. According to the psychometric paradigm, people also perceive the risk with a degree 
of immediacy (Dohle et al., 2010). Generally, in the case of COVID-19, people are perceiving both cognitive and affective risk because this virus is uncontrollable and effecting immediately to one another. In contrast to the psychometric paradigm approach, expectancy-value models have concentrated on how perceived risk effect people purchasing choices and behaviour (Eccles \& Wigfield, 2002). Simply, this model is based on human judgment and choices. It is based on the expected utility approach and according to this approach, people's decision choices of purchasing are a result of probability and desirability of options (Savage, 1954). In a nutshell, the psychometric paradigm approach identifies the level of risk and expectancy-value approach to determine how risk influences consumer purchase intentions.

\section{Perceived Risk and Purchase Intention}

Perceived risk can be defined as the uncertainty with a chance of something terrible happening in the future when going to purchase a product, especially expensive products like cars, laptops, and diamonds because we are investing a heavy amount (Lu et al., 2016). Perceived risk diminishes the intentions of consumers to purchase a product when consumers are involved in risky shopping (Masoud, 2013). Purchase intention is the psychological phase in decision-making when consumers create a real willingness to purchase a product or brand (Thakur and Srivastava, 2015). Perceived risk has a direct negative effect on consumer transaction intentions. When consumers perceived higher risk,

they are motivated to evade the transaction and they will not willing to purchase the product until they are sure they can expect a positive return after a transaction (Tuu et al., 2011). Consumer shows resistance toward expensive purchasing during uncertain situations because of heavy investment. People prioritize their purchasing due to financial uncertainty. On normal days people prefer to try an innovative expensive product that represents they are fine and comfortable with the cost of brands. Therefore, it can be hypothesized that:

H1 \# There is a negative and significant relationship between perceived risk and consumer purchase intention towards the luxury brands in the case of COVID-19.

\section{Fear and Perceived Risk}

Humans' emotions are an effective state of mind. All emotions are very effective, either negative or positive. Fear is a negative emotion that happens as a result of an uncertain situation (Terpstra, 2011). It is defined as the overestimation of risk associated with the situation (Hengen \& Alpers, 2019). Fear increases the intuition of the probability that a negative outcome will occur. Consumer fear occurs as a self. protection mechanism and results in escape and withdrawal to expel from a potentially hazardous situation to avoid risk (Loewenstein \& Lerner, 2003).

Risk and fear are frequently considered as one idea because both ultimately change the consumer decision, but previous definitions have demonstrated a difference (Ko et al., 2010). Therefore, perceived risk and fear are related to each other. Weber (2006) revealed that the relationship between perceived risk and fear is not linear. A higher degree of consumer fear after the first perceived risk does not crucial to correlate with expansion in risk. Increased fear may be due to temporal perception, when risk moves close (Loewenstein, 2000). Some other factors contribute to the elicitation of fear in which may include media and their personal experience. (Hutjens, 2014) Thus, perceived risk and fear have various determinants (Loewenstein, 2000). On the other side, it is also revealed that perceived risk is the precedent of fear (Warr,1987; Rountree and Land, 1996). Consumer interprets the stimuli in their environment and utilizes this to identify the perceived risk which elicits the fear and ultimately results in withdrawal. So, it is suggested that a parallel expansion between risk and fear, the high perceived risk would elicit more fear as compared to low risk, especially when something dangerous is expected. Therefore, it can be hypothesized that: 
H2 \#There is a positive significant relationship between perceived risk and fear in the case of COVID-19.

\section{Fear and Purchase Intentions}

The fear of consumers has a direct effect on consumer purchase intentions that prevent dissatisfaction (Makkonen et al.,2019). It influences how people spend their money on recreational exercises, accommodation, food, luxury buying, and transport, etc. According to Zeelenberg \& Pieters (2006), emotions have a strong effect on consumer ensuing actions. When an individual perceived a threat state, it usually evokes fear and fear motivates them to flee from the situation and avoid confrontation (Roseman $e t$ al., 1994). So, it is a hypothesis that;

H3 \# There is a negative and significant relationship between fear and consumer purchase intention towards the luxury brands in the case of COVID-19.

\section{Perceived Risk, Fear, and Purchase Intention}

Our emotions (positive or negative) are paired with perceived risk, we mostly fear with those events that are more than a common event. In the case of deadly COVID-19, people's risk perception is especially thorny because the knowledge of disease is yet evolving. According to Weber (2006) fear function act as a motivation factor to decrease or remove a feeling of risk and take action accordingly. Commonly when there is no horrible situation, consumers are extremely reluctant to change their buying intention towards branded products because habit is more grounded than consumer intentions (Vermeir and Verbeke, 2006). A Change in consumer intention needs to be stronger enough that impelled by fear.

According to Lobb et al. (2007), during an uncertain situation, perceived risk leads to a change in purchase intention towards branded items, however, fear is not including here. On the other side, it is also debated when a consumer is very fearful about the forthcoming situation then he will drastically change the purchasing behaviour toward products (Hutjens, 2014). Therefore, it is assumed that fear might be working as a moderator between consumer perceived risk and the purchase intention, it can be hypothesized that:

H4 \# Fear may negatively strengthen the relationship between perceived risk and purchase intention toward luxury brands in the case of COVID-19.

Based on the literature review, a conceptual framework is depicted in figure1. The framework represents the linkage between COVID-19 (event), perceived risk, purchase intention, and fear as a moderator.

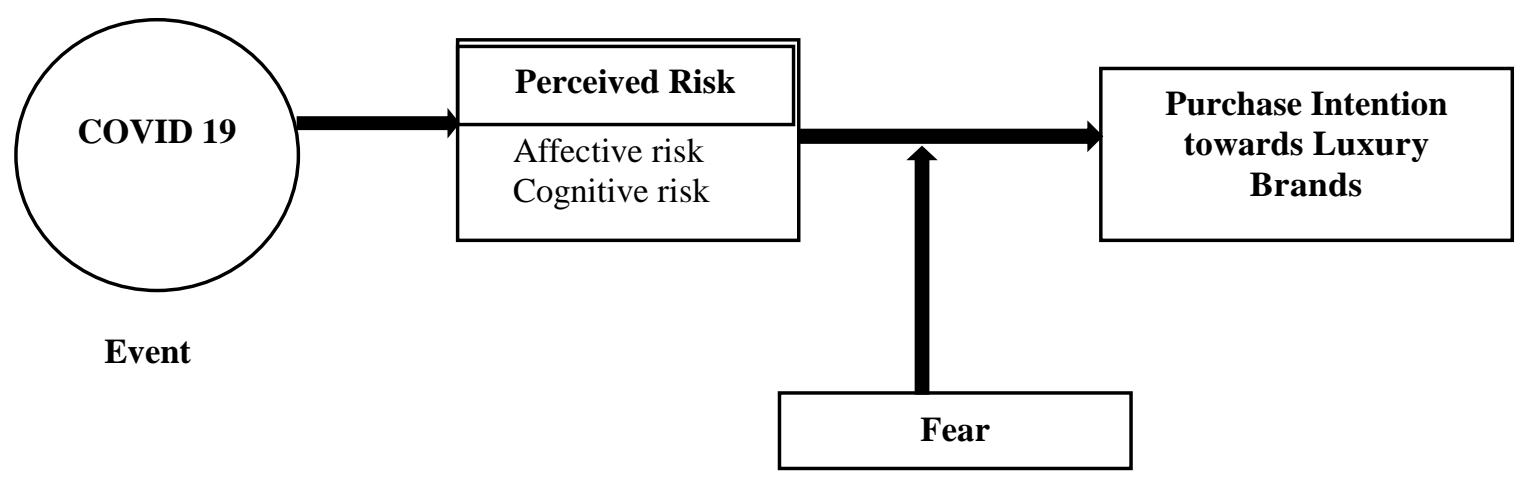

Figure 1: Conceptual Framework. 


\section{Research Methodology}

In this study, to determine the consumer's purchase intention during a pandemic, we collect our primary data from Pakistani consumers who are the users of luxury. And the contact details of consumers who are the users of luxury items are collected from the outlets of brands. A structural questionnaire was developed after an extensive review of extant literature, consist of twenty-one items include both background and variables related questions. This study was based on the deductive study and adopted a quantitative method with a purposive sampling technique. The consumers were contacted by phone or by email and requested to participate in an academic study. An online questionnaire was disseminated to the 780 consumers and 750 valid responses were returned. SPSS was used for data analysis. The research questionnaire consisted of four sections with 21 items: (1) background information, (2) perceived risk (3) fear, and (4) purchase intention. Firstly, various socio-demographic variables were included in the questionnaire. Secondly, perceived risk (PR) measures were adopted from Trumbo et al. (2016). Thirdly, fear (FR) measures were adopted from Simard \& Savard (2009). Lastly, Purchase intention (PI) measurement was adopted from Phan \& Mai (2016). A five-point Likert- scale was used for all items (1 - "strongly disagree" to 5 "strongly agree").

\section{Results}

Results of demographic characteristics depicted that, more than 45 percent of the participants were female and the rest were male. A large number of participants were aged between 26 to 41 . The majority were well educated, had a salary of more than 75000 , and located in urban areas as portrayed in Table 1.

Table 1: Demographic Information

\begin{tabular}{|lccc|}
\hline Name & Frequency & Percent & Cumulative Percentage \\
\hline 1.Gender & & & \\
female & 370 & 49.3 & 49.3 \\
male & 380 & 50.7 & 100.0 \\
2.Age & & & \\
18-25 years & 213 & 28.4 & 28.4 \\
26-33 years & 386 & 51.5 & 79.9 \\
34-41years & 93 & 12.4 & 92.3 \\
Older than 42 & 58 & 7.7 & 100.0 \\
3. Income range & & & \\
less than 25000 & 29 & 3.9 & 3.9 \\
25000-50000 & 63 & 8.4 & 12.3 \\
50000-75000 & 115 & 15.3 & 27.6 \\
75000-100000 & 286 & 38.1 & 100.7 \\
above100000 & 257 & 34.3 & \\
4.Education level & & & 5.6 \\
Equal or less than & 42 & 5.6 & 28.7 \\
Intermediate & 173 & 23.1 & 78.7 \\
Equal or less than graduate & 375 & 50.0 & 97.1 \\
Master degree holder & 138 & 18.4 & 97.6 \\
M.Phil (18 years) & 4 & .5 & 100.0 \\
Doctoral degree & 18 & 2.4 & 75.5 \\
Others & & & 100.0 \\
5.Location & 566 & 75.5 & \\
urban & 183 & 24.4 & \\
rural & & & \\
\hline
\end{tabular}


The study used exploratory factor analysis for the factor extraction. During the alteration of the first unfitted model, one item of PR (PRA4) was deleted. A total of three factors and 61 percent variation in data were identified by the factor's solution. The value of Kaiser Meyer-Olken was .889 and the overall reliability score was more than 0.7 which has represented a very good internal consistency of the items together (Nunnally \& Bernstein, 1994). Due to the result of EFA, all items of PRA and PRC were merged into one factor (PR). A summary of the factor loading, variance percentage, and alpha is depicted in Table 2.

Table 2: EFA Measurement model

\begin{tabular}{|c|c|c|c|c|c|}
\hline variables & $\begin{array}{l}\text { Items } \\
\text { codes }\end{array}$ & statements & $\begin{array}{l}\text { Factor } \\
\text { loading }\end{array}$ & $\begin{array}{l}\text { Variance } \\
\%\end{array}$ & Alpha \\
\hline \multirow[t]{13}{*}{$\begin{array}{l}\text { Perceived } \\
\text { Risk (PR) }\end{array}$} & $\begin{array}{l}\text { PRA, } \\
\text { PRC }\end{array}$ & & & $36 \%$ & .911 \\
\hline & PRA1 & COVID-19 Makes me feel fearful. & .498 & & \\
\hline & PRA2 & COVID-19Makes me feel worried. & .673 & & \\
\hline & PRA3 & COVID-19Makes me feel dread. & .817 & & \\
\hline & PRC1 & $\begin{array}{l}\text { I think that COVID- } 19 \text { may cause } \\
\text { catastrophic destruction. }\end{array}$ & .732 & & \\
\hline & $\mathrm{PRC} 2$ & $\begin{array}{l}\text { I think that COVID-19 may cause widespread } \\
\text { death }\end{array}$ & .652 & & \\
\hline & PRC3 & $\begin{array}{l}\text { I think COVID-19 poses a great financial } \\
\text { threat. }\end{array}$ & .638 & & \\
\hline & PRC4 & $\begin{array}{l}\text { I think COVID-19 poses a threat to future } \\
\text { generations. }\end{array}$ & .839 & & \\
\hline & & & & & .792 \\
\hline & & $\begin{array}{l}\text { My feeling of fear for consequences of } \\
\text { COVID-19 is high }\end{array}$ & .583 & & \\
\hline & $\mathrm{F} 2$ & $\begin{array}{l}\text { My feeling of fear of contracting COVID-19 } \\
\text { and becoming ill is high }\end{array}$ & .641 & & \\
\hline & F3 & $\begin{array}{l}\text { My feeling of fear of someone I know } \\
\text { contracting COVID-19 and becoming ill is } \\
\text { high }\end{array}$ & .462 & & \\
\hline & F4 & $\begin{array}{l}\text { My feeling of fear about Coronavirus disease, } \\
\text { in general, is high }\end{array}$ & .498 & & \\
\hline \multirow{5}{*}{$\begin{array}{l}\text { Purchase } \\
\text { Intention } \\
\text { (PI) }\end{array}$} & & & & $9 \%$ & .750 \\
\hline & PI1 & $\begin{array}{l}\text { I would continue purchasing luxury brands in } \\
\text { this pandemic. }\end{array}$ & .923 & & \\
\hline & PI2 & $\begin{array}{l}\text { I would purchase luxury brands at least once } \\
\text { a week in this pandemic. }\end{array}$ & .879 & & \\
\hline & PI3 & $\begin{array}{l}\text { I plan to increase the frequency of purchasing } \\
\text { for a luxury brand in this pandemic. }\end{array}$ & .910 & & \\
\hline & PI4 & $\begin{array}{l}\text { I am eager to recommend my friends, } \\
\text { colleague, and family to buy luxury brands in } \\
\text { this pandemic. }\end{array}$ & .841 & & \\
\hline Total & & & & $61 \%$ & \\
\hline
\end{tabular}




\section{Hypothesis Testing and Analysis}

H1 was confirmed as perceived risk has a negative significant influence on consumer purchase intention towards the luxury brand in the case COVID-19 $(\beta$ value $=-.293$ and $\mathrm{p}$-value $<.001) . \mathrm{H} 2$ was also accepted as perceived risk has a positive significant relationship with fear ( $\beta$ value $=0.784$ and $p$-value $<.001)$. $\mathrm{H} 3$ was also confirmed as there is a negative relation between fear and consumer purchase intention towards the luxury brand in the COVID-19 ( $\beta$ value $=-.342$ and $p$-value < .001 ). A detailed summary of regression is portrayed in table 3 .

Table 3: Hypothesis testing

\begin{tabular}{|cccccc|}
\hline Hypothesis & Regression analysis Path & $\beta$-value & t-value & p-value & Result \\
\hline H1 & PR $\rightarrow$ PI & -.293 & -8.374 & .000 & supported \\
H2 & PR $\rightarrow$ FR & .784 & 34.548 & .000 & supported \\
H3 & FR $\rightarrow$ PI & -.342 & -9.960 & .000 & supported \\
\hline
\end{tabular}

H4 was significantly accepted. For determining the moderation effect of fear (FR), a hierarchical moderated regression analysis that consists of three steps was run to test the research hypothesis as portrayed in Table 4. Firstly, purchase intention (PI) was regressed with perceived risk (PR). Secondly, consumer purchase intention was regressed with both perceived risk (independent variable) and Fear (moderating) variable. In the last step of regression, an interaction term was made by multiplying perceived risk (Independent variable) with fear (moderation). Direct support was available for the moderation effect of Fear (FR) on the relation of perceived risk (PR) and consumer purchase intention (PI), while in interaction term the beta value of Fear (FR) with perceived risk (PR) was $-1.392, p<0.001$. It is demonstrated that fear to a great extent negatively affects as a moderator as portrayed in Figure 2.

Table 4: Detail Summary of Moderation test

\begin{tabular}{|l|l|l|l|}
\hline \multicolumn{5}{|c|}{ Moderating role of Fear (Regression, 1, 2, 3) } \\
\hline R2 & .086 & .119 & .155 \\
\hline Adj. R2 & .084 & .116 & .155 \\
\hline F & 70.131 & 50.281 & 45.456 \\
\hline Independent variable & & & $.608 * * *$ \\
Perceived Risk (PR) & $-.293 * * *$ & $.064 * *$ & \\
\hline Moderating variable & & & $.496 * * *$ \\
Fear (FR) & & $-.292^{* * *}$ & \\
\hline $\begin{array}{l}\text { Interaction Terms } \\
\text { FRPR (Fear, Perceived Risk,) }\end{array}$ & & & $-1.392^{* * *}$ \\
Notes: $* *$ p $<0.005 ; * * * p<0.001 ;$ & & & \\
\hline
\end{tabular}




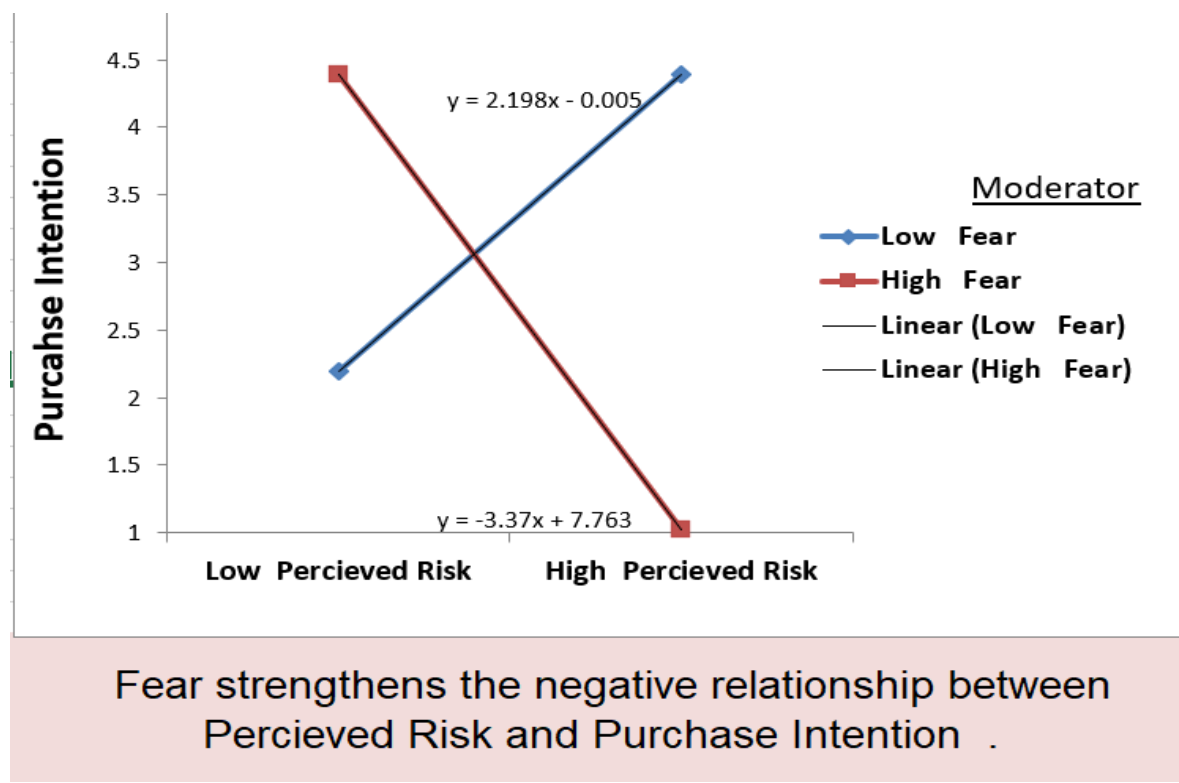

Figure 2: Fear strengthens the negative relationship between perceived risk and consumer purchase intention.

\section{Discussion}

The finding interpreted that when consumers perceived some doubt from the desired stage to the actual stage of a product then they will not move into the action stage. In a normal situation, people prefer to try an innovative expensive product that represents they are fine with the cost of brands (Raheem et al., 2014). But in the case of the COVID-19 outbreak, people are perceiving high risk because of the constant negative bombardment of this virus on the economy, and they put a hold on their purchasing, especially luxury items. This finding is congruent with the previous scholar work who postulates that perceived risk is negatively influenced by purchase intention (Chang \& Chen, 2008; Kim et al., 2013). The study also revealed the effect of consumer perceived risk on fear in the case COVID-19. When consumers perceived a higher risk during a hazardous situation, it usually evokes fear. In the current situation of COVID-19, people fear due to higher risk has been reached such a level that World Health Organization (WHO) suggested some guidelines to cope with mental health which is; to abstain from reading, listening, or watching the news that causes distress and follows information for practical steps that protect you. This finding is congruent with the previous scholar work who postulates that when the consumer in their proximity is influenced by the outbreak, their perceived risk and fear together increased significantly (Loewenstein \& Lerner, 2003; Sohani \& Fahmy, 2020).

The study confirmed the moderating role of fear between perceived risk and purchase intention towards luxury brands in the case of COVID-19. In the current situation, consumers are showing resistance toward purchasing brands due to a high perceived risk of life and death. While consumers who are also fearful due to this deadly virus have shown a drastic decrease in their purchase intention towards luxury. It is not essential perceived risk leads to fear, some other determinants elicit fear. But the presence of fear between risk and intention strengthens their negative relation. This finding is congruent with the previous scholar work who posits that highly negative emotion (fear) about forthcoming rapidly changes purchasing desire (Hutjens, 2014). When there is no uncertain situation, consumers are reluctant to alter their intentions easily towards brands because habit is more grounded than consumer intentions that impelled by fear (Young et al., 2010). Natural disasters have a deep impact on marketers because it effects on consumer shopping behavior (Rai et al., 2017). 


\section{Managerial Implications}

The study has some mandatory implications for market players, especially in the case of an outbreak. The finding indicated that fear plays a dominant role in altering the purchase intention that has not been exposed before. The result contributes to the existing knowledge, although natural crisis is not under control, marketers should prepare some strategies in advance that control negative emotions of consumers for shopping. As in the case of Covid-19, consumers are in the great depression of life and death and many of them are expecting that their income will fall soon in the coming months. At this point, companies need to not only focus on sales but also build trust with their fearful consumers which will be valuable in the long run. This could be done in various ways: simply messages for support, providing help to those who directly suffered from the disaster, and do some kind of charitable activity for cleanup. This exploration is very useful for the luxury industry for their prospect, if they encounter any deadly virus.

\section{Conclusion and Further Research Directions}

This study explores the relations between perceived risk, fear, and consumer purchase intention towards luxury brands in the case of COVID-19. Considering the uniqueness of the study, it is based on two theories include Psychometric Paradigm and Expectancy-Value model that explains how perceived risk declines the consumer purchase intention during an outbreak. The study confirmed the moderating role of fear between perceived risk and purchase intention towards luxury brands in the case of COVID-19. It is concluded that consumer perceived risk leads to a decline in purchase intention but consumers who are also fearful would drastically decrease their purchase intention. Future researchers need to research ways that dilute fear during hazard situations. During making this work it has been clear that still the element of fear is exposed insufficiently. Therefore, this work will be helpful for other researchers, who want to add a fear element to their model.

\section{References}

Bonnet, E., Amalric, M., Chevé, M., \& Travers, M. (2012). Hazard and living environment: Combining industrial risk and landscape representations. Journal of risk research, 15(10), 1281-1298.

Chang, H. H., \& Chen, S. W. (2008). The impact of online store environment cues on purchase intention. Online information review. 3(6),818-841.

Chen, N., Zhou, M., Dong, X., Qu, J., Gong, F., Han, Y., \& Yu, T. (2020). Epidemiological and clinical characteristics of 99 cases of 2019 novel coronavirus pneumonia in Wuhan, China: a descriptive study. The Lancet, 395(10223), 507-513.

Dohle, S., Keller, C., \& Siegrist, M. (2010). Examining the relationship between affect and implicit associations: Implications for risk perception. Risk Analysis: An International Journal, 30(7), 11161128.

Dursun, I., Kabadayı, E. T., Alan, A. K., \& Sezen, B. (2011). Store brand purchase intention: Effects of risk, quality, familiarity and store brand shelf space. Procedia-Social and Behavioural Sciences, 24, 1190-1200.

Eccles, J. S., \& Wigfield, A. (2002). Motivational beliefs, values, and goals. Annual review of psychology, 53(1), 109-132.

Fung, T. K., Namkoong, K., \& Brossard, D. (2011). Media, social proximity, and risk: A comparative analysis of newspaper coverage of avian flu in Hong Kong and in the United States. Journal of health communication, 16(8), 889-907.

Grima, S., Özen, E., Boz, H., Spiteri, J. and Thalassinos, E. (2019). Contemporary Issues in Behavioural Finance (Contemporary Studies in Economic and Financial Analysis, Vol. 101), Emerald Publishing Limited, 101, 1-22.

Hengen, K. M., \& Alpers, G. W. (2019). What' s the risk? Fearful individuals generally overestimate negative outcomes and they dread outcomes of specific events. Frontiers in psychology, 10, 1676. 
Huang, C., Wang, Y., Li, X., Ren, L., Zhao, J., Hu, Y., ... \& Cheng, Z. (2020). Clinical features of patients infected with 2019 novel coronavirus in Wuhan, China. The lancet, 395(10223), 497-506.

Hutjens, M. (2014). The influence of fear on the buying behaviour of consumers in case of an animal disease outbreak. Wageningen University: Wageningen, The Netherlands.

Kapferer, J. N., \& Bastien, V. (2009). The specificity of luxury management: Turning marketing upside down. Journal of Brand Management, 16(5-6), 311-322.

Kapferer, J. N., \& Valette-Florence, P. (2018). The impact of brand penetration and awareness on luxury brand desirability: A cross country analysis of the relevance of the rarity principle. Journal of Business Research, 83, 38-50.

Khan, N. A. (2020). Outbreak of Covid-19: Its Impact on Brand Health and Marketing Communications. Business Review.

Kim, J., \& Lennon, S. J. (2013). Effects of reputation and website quality on online consumers' emotion, perceived risk and purchase intention. Journal of Research in Interactive Marketing.7 (1),33-56.

Ko, C. H., Hsiao, S., Liu, G. C., Yen, J. Y., Yang, M. J., \& Yen, C. F. (2010). The characteristics of decision making, potential to take risks, and personality of college students with Internet addiction. Psychiatry research, 175(1-2), 121-125.

Lee, J. E., Lemyre, L., \& Krewski, D. (2010). A Multi-Method, Multi-Hazard Approach to Explore the Uniqueness of Terrorism Risk Perceptions and Worry 1. Journal of Applied Social Psychology, 40(1), 241-272.

Leppin, A., \& Aro, A. R. (2009). Risk perceptions related to SARS and avian influenza: theoretical foundations of current empirical research. International journal of behavioural medicine, 16(1), 7-29.

Lobb, A. E., Mazzocchi, M., \& Traill, W. B. (2007). Modelling risk perception and trust in food safety information within the theory of planned behaviour. Food quality and preference, 18(2), 384-395.

Loewenstein, G. (2000). Emotions in economic theory and economic behaviour. American economic review, 90(2), 426-432.

Loewenstein, G., \& Lerner, J. S. (2003). The role of affect in decision making. Handbook of affective science, 619(642), 3.

Mai, P. H. (2016). Determinants Impacting Consumersi ${ }^{-}$Purchase Intention: The Case of Fast Food in Vietnam. International Journal of Marketing Studies, 8(5),56-68.

Makkonen, M., Riekkinen, J., Frank, L., \& Jussila, J. (2019). The effects of positive and negative emotions during online shopping episodes on consumer satisfaction, repurchase intention, and recommendation intention. In Bled eConference. University of Maribor.

Masoud, E. Y. (2013). The effect of perceived risk on online shopping in Jordan. European Journal of Business and Management, 5(6), 76-87.

Nunnally, J. C., \& Bernstein, I. H. (1994). Validity. Psychometric theory, 3, 99-132.

Oh, S. H., Paek, H. J., \& Hove, T. (2015). Cognitive and emotional dimensions of perceived risk characteristics, genre-specific media effects, and risk perceptions: the case of H1N1 influenza in South Korea. Asian Journal of Communication, 25(1), 14-32.

Raheem, A. R., Vishnu, P., \& Ahmed, A. M. (2014). Impact of product packaging on consumer's buying behavior. European journal of scientific research, 122(2), 125-134.

Rai, D., Lin, C. W. W., \& Yang, C. M. (2017). The effects of temperature cues on charitable donation. Journal of Consumer Marketing.

Roseman, I. J., Wiest, C., \& Swartz, T. S. (1994). Phenomenology, behaviours, and goals differentiate discrete emotions. Journal of personality and social psychology, 67(2), 206.

Rosenstock, I. M., Strecher, V. J., \& Becker, M. H. (1988). Social learning theory and the health belief model. Health education quarterly, 15(2), 175-183.

Rountree, P. W., \& Land, K. C. (1996). Perceived risk versus fear of crime: Empirical evidence of conceptually distinct reactions in survey data. Social forces, 74(4), 1353-1376.

Ruiz-Mafe, C., Chatzipanagiotou, K., \& Curras-Perez, R. (2018). The role of emotions and conflicting online reviews on consumers' purchase intentions. Journal of Business Research, 89, 336-344. 
Savage, L. J. (1961). The foundations of statistics reconsidered. In Proceedings of the Fourth Berkeley Symposium on Mathematical Statistics and Probability, Volume 1: Contributions to the Theory of Statistics. The Regents of the University of California.

Shaikh, S., Malik, A., Akram, M. S., \& Chakrabarti, R. (2017). Do luxury brands successfully entice consumers? The role of bandwagon effect. International Marketing Review.34(4),498-513.

Simard, S., \& Savard, J. (2009). Fear of Cancer Recurrence Inventory: development and initial validation of a multidimensional measure of fear of cancer recurrence. Supportive care in cancer, 17(3), 241-251.

Slovic, P. E. (2000). The perception of risk. Earthscan publications.

Sohani, A., \& Fahmy, T. (2020). The impact of a pandemic on brand preference in purchasing decisions of food and hygiene products: a COVID-19 perspective.

Strahilevitz, M. (2020). Will Sustainable Fashion Ever Beat Value Fashion?

Terpstra, T. (2011). Emotions, trust, and perceived risk: Affective and cognitive routes to flood preparedness behaviour. Risk Analysis: An International Journal, 31(10), 1658-1675.

Thakur, R., \& Srivastava, M. (2015). A study on the impact of consumer risk perception and innovativeness on online shopping in India. International Journal of Retail \& Distribution Management.43(2),148-166.

Trumbo, C. W., Peek, L., Meyer, M. A., Marlatt, H. L., Gruntfest, E., McNoldy, B. D., \& Schubert, W. H. (2016). A cognitive-affective scale for hurricane risk perception. Risk analysis, 36(12), 2233-2246.

Tuu, H. H., Olsen, S. O., \& Linh, P. T. T. (2011). The moderator effects of perceived risk, objective knowledge and certainty in the satisfaction-loyalty relationship. Journal of Consumer Marketing. 28(5),363-375.

Vermeir, I., \& Verbeke, W. (2006). Sustainable food consumption: Exploring the consumer "attitudebehavioural intention" gap. Journal of Agricultural and Environmental ethics, 19(2), 169- 194.

Warr, M. (1987). Fear of victimization and sensitivity to risk. Journal of quantitative criminology, 3(1), 2946.

Weber, E. U. (2006). Experience-based and description-based perceptions of long-term risk: Why global warming does not scare us (yet). Climatic change, 77(1-2), 103-120.

Xu, X., Zhang, L., Chen, L., \& Wei, F. (2020, June). Does COVID-2019 have an Impact on the Purchase Intention of Commercial Long-Term Care Insurance among the Elderly in China? In Healthcare (Vol. 8, No. 2, p. 126). Multidisciplinary Digital Publishing Institute. 8(2), 126.

Young, W., Hwang, K., McDonald, S., \& Oates, C. J. (2010). Sustainable consumption: green consumer behaviour when purchasing products. Sustainable development, 18(1), 20-31.

Zeelenberg, M., Nelissen, R. M., Breugelmans, S. M., \& Pieters, R. (2008). On emotion specificity in decision making: Why feeling is for doing. Judgment and Decision making, 3(1), 18.

Zheng, L., Favier, M., Huang, P., \& Coat, F. (2012). Chinese consumer perceived risk and risk relievers in e-shopping for clothing. Journal of Electronic Commerce Research, 13(3), 255. 